ISSN: 2302-8556

E-Jurnal Akuntansi Universitas Udayana

Vol.25.3.Desember (2018): 2155- 2184

DOI: https://doi.org/10.24843/EJA.2018.v25.i03.p20

\title{
Pengaruh Pengendalian Internal, Budaya Organisasi, Dan Moralitas Pada Kecenderungan Kecurangan (Fraud) Di Lpd Se-Kabupaten Gianyar
}

\section{Putu Aditya Prastika Eka Putra ${ }^{1}$ \\ Made Yenni Latrini ${ }^{2}$}

\begin{abstract}
${ }^{1}$ Fakultas Ekonomi dan Bisnis Universitas Udayana (Unud), Bali, Indonesia email: adityaprastika15@ gmail.com/ Telp: +62 89520566872

${ }^{2}$ Fakultas Ekonomi dan Bisnis Universitas Udayana (Unud), Bali, Indonesia
\end{abstract}

\begin{abstract}
ABSTRAK
Penelitian ini bertujuan untuk mengetahui Pengaruh Pengendalian Internal, Budaya Organisasi, dan Moralitas pada Kecenderungan Kecurangan (Fraud) di LPD se-Kabupaten Gianyar. Teori yang digunakan dalam penelitian ini adalah Fraud Triangle Theory dan Agency Theory. Populasi dalam penelitian ini adalah LPD se-Kabupaten Gianyar. Penelitian ini menggunakan teknik Proportionate stratified random sampling. Sampel diambil sebanyak 73 Kepala LPD. Pengumpulan data dilakukan dengan metode kuesioner. Teknik analisis data yang digunakan adalah analisis regresi linear berganda. Hasil penelitian ini menunjukkan bahwa Pengendalian Internal, Budaya Organisasi, dan Moralitas berpengaruh negatif pada Kecenderungan Kecurangan (Fraud) di LPD seKabupaten Gianyar.
\end{abstract}

Kata Kunci: Pengendalian Internal, Budaya Organisasi, Moralitas, Kecenderungan

\begin{abstract}
This research aimed to determine the effect of internal control, organizational culture, and morality to fraud tendency. The theory used in this research are Fraud Triangle Theory and Agency Theory. The population in this study is the head of LPDs in Gianyar regency. This research using proportionate stratified random sampling. The samples were taken are 73 head of LPDs. The data collectment is done by questionnaire method. The data analysis technique used in this research is multiple linear regression technique. The results of this research showed that internal control, cultural organization and morality have negative affect on fraud tendency in LPDs in Gianyar regency.

Keywords: Internal Control, Organizational Culture, Morality, Fraud Tendency
\end{abstract}

\section{PENDAHULUAN}

LPD merupakan badan usaha keuangan milik desa pakraman yang melakukan kegiatan operasionalnya di lingkungan desa pakraman untuk melayani masyarakat desa setempat. LPD bertujuan untuk mendorong pembangunan ekonomi pada masyarakat desa melalui pemberian kredit maupun simpanan dalam bentuk tabungan. Peran LPD sangat penting dalam meningkatkan perekonomian masyarakat. Pentingnya peranan 
LPD bagi masyarakat, maka pengurus atau pengelola LPD harus meningkatkan produktivitasnya agar mampu bersaing dengan lembaga keuangan lainnya (Wijayanti, 2012). Selain melakukan kegiatan pemberian modal, LPD juga menciptakan kesempatan dan pemerataan kerja bagi warga pedesaan dengan bekerja secara langsung di LPD. Namun, Ditengah pertumbuhan LPD yang pesat terdapat salah satu kasus penyalahgunaan dana nasabah yang terjadi di LPD Suwat yang berlokasi di Kabupaten Gianyar, Provinsi Bali. Tahun 2010 dilakukan peralihan sistem pengelolaan LPD dari manual menjadi sistem komputerisasi. Saat itu ditemukan adanya selisih antara di buku tabungan dengan catatan yang ada di LPD hingga Rp 68 juta. Hal ini disebabkan oleh pencatatan administrasi keuangan terkait tabungan yang diduga dilakukan secara tidak benar. Kasus ini diperkirakan terjadi sampai dengan tahun 2015 (balipost.com). Selain itu, kasus fraud juga terjadi di LPD Belaluan, Gianyar. Kejaksaan menetapkan Ketua Lembaga Perkreditan Desa (LPD) Belaluan, Kabupaten Gianyar, sebagai tersangka penggelapan uang nasabah senilai Rp700 juta (bali.antaranews.com). Selain di LPD Suwat dan Belaluan, ada juga kasus fraud yang terjadi di LPD Kerta, Kabupaten Gianyar. Dimana, Ketua LPD Desa Kerta, Payangan Gianyar, terbukti secara sah dan meyakinkan melakukan tindak pidana korupsi dengan cara menyalahgunakan kewenangan untuk menguntungkan diri sendiri Rp 104 juta dan orang lain (bali.tribunnews.com).

Hal ini secara jelas mengindikasikan telah banyaknya terjadi kasus kecurangan yang dilakukan oleh oknum yang merugikan lembaga keuangan tersebut dan pihak lain yang bersangkutan. Selain itu berdasarkan Pansus LPD DPRD Provinsi Bali dari 
ISSN: 2302-8556

E-Jurnal Akuntansi Universitas Udayana

Vol.25.3.Desember (2018): 2155- 2184

seluruh LPD yang berada di Kabupaten/Kota Provinsi Bali, LPD di Kabupaten Gianyar menjadi yang paling banyak masuk kategori tidak sehat yakni, 15 LPD dari total 38 LPD yang digolongkan kategori tidak sehat di Provinsi Bali (balitribune.co.id). Hal ini berarti 39,5 \% dari LPD yang digolongkan kategori tidak sehat di Provinsi Bali berada di Kabupaten Gianyar.

Tabel 1.

Data Pansus LPD DPRD Provinsi Bali mengenai Jumlah LPD di Bali yang masuk Kategori Tidak Sehat

\begin{tabular}{lll}
\hline NO & Kabupaten & Jumlah \\
\hline 1 & Gianyar & 15 \\
2 & Tabanan & 8 \\
3 & Buleleng & 6 \\
4 & Badung & 4 \\
5 & Karangasem & 2 \\
6 & Bangli & 2 \\
7 & Klungkung & 1 \\
8 & Denpasar & 0 \\
Total & & 38 \\
Sumber $:$ www.balitribune.co.id, 2017 &
\end{tabular}

Kecurangan merupakan suatu tindakan yang dilakukan oleh seseorang maupun kelompok secara sengaja yang berdampak dalam laporan keuangan dan dapat mengakibatkan kerugian bagi entitas atau pihak lain. Menurut Badan Pemeriksa Keuangan (BPK) RI (2007) fraud didefinisikan sebagai suatu jenis tindakan melawan hukum yang dilakukan dengan sengaja untuk memperoleh sesuatu dengan cara menipu. Kecurangan dapat dijelaskan dengan Fraud Triangle Theory. Seseorang melakukan kecurangan dimungkinkan oleh adanya tekanan (pressure), kesempatan (opportunity), dan rasionalisasi (rationalization). Dari ketiga faktor tersebut, kesempatan adalah yang paling mungkin diminimalisir dengan pengendalian internal yang baik. 
Dorminey (2011) menyatakan bahwa faktor rasionalisasi dan tekanan merupakan karakteristik pelaku kecurangan akuntansi yang tidak dapat diobservasi karena mustahil untuk mengetahui apa yang dipikirkan oleh pelaku ketika akan melakukan kecurangan akuntansi. Hernandez dan Groot (2007) menemukan bahwa etika dan lingkungan pengendalian akuntansi merupakan dua hal yang sangat penting terkait kecenderungan seseorang dalam melakukan kecurangan akuntansi. Menurut Sukanto (2009) dalam Yanita (2015), Fraud merupakan penipuan yang sengaja dilakukan yang menimbulkan kerugian pihak lain dan memberikan keuntungan bagi pelaku kecurangan dan atau kelompoknya. Organisasi yang memiliki peluang paling besar terjadinya kecurangan (Fraud) adalah organisasi yang bergerak dibidang keuangan atau di lembaga keuangan. Kecurangan mengakibatkan penyimpangan yang terjadi dalam laporan keuangan sehingga mengakibatkan informasinya menjadi tidak relevan. Menurut Saputra (2015) tindakan yang dilakukan dapat berupa penghilangan jumlah atau pengungkapan dalam laporan keuangan untuk mengelabui pemakai laporan keuangan. Tindakan penyimpangan dalam laporan keuangan ini merupakan salah satu tindakan kecurangan akuntansi.

Menurut Coram (2008), Organisasi yang memiliki fungsi audit internal akan lebih dapat mendeteksi kecurangan akuntansi. Dalam hal ini, pengawasan menjadi penting dalam pencegahan kecurangan yang terjadi dalam suatu instansi. Peranan badan pengawas internal sebagai pengawas internal sangat strategis, di samping sebagai auditor internal juga sebagai partner yang bersinergi untuk memajukan LPD. Di bali, Badan Pengawas Internal ini disebut dengan istilah panureksa. Panureksa ini 
ISSN: 2302-8556

diketuai oleh Bendesa adat setempat. Ketua badan pengawas internal yang dijabat oleh bendesa adat dimaksudkan untuk menciptakan suatu lingkungan pengendalian yang kondusif dan efektif. Berdasarkan Peraturan Gubernur Bali No 3 Tahun 2017 Bab XI Pasal 20, untuk meningkatkan pengawasan terhadap LPD maka, LPD wajib melakukan audit 1 (satu) kali dalam 1 (satu) tahun dimana audit ini dapat dilakukan oleh Panureksa atau Badan Pengawas Internal, Lembaga Pemberdayaan Lembaga Perkreditan Desa (LPLPD), serta Lembaga Auditor yang ditunjuk oleh Tim Pembina Umum Kabupaten/Kota yang ditetapkan oleh Bupati/Walikota.

Pengendalian internal merupakan proses yang dijalankan untuk memberikan keyakinan memadai tentang pencapaian keandalan laporan keuangan, kepatuhan terhadap hukum, dan efektivitas dan efisiensi operasi (Tunggal, 2011). Pengendalian internal memiliki peranan penting dalam organisasi untuk meminimalkan terjadinya suatu kecurangan. Pengendalian internal yang rendah dan kepatuhan karyawan terhadap pengendalian internal yang juga rendah dapat menjadi pemicu terjadinya kecurangan (Fraud) di sektor pemerintahan.

Menurut Sulistiyowati (2007), Budaya Organisasi yang baik tidak akan membuka peluang sedikit pun bagi individu untuk melakukan fraud karena budaya organisasi yang baik akan membentuk orang-orang di dalam organisasi memiliki sense of belonging (rasa ikut memiliki) dan sense of identity (rasa bangga sebagai bagian dari organisasi). Budaya sebagai faktor informal yang berpengaruh terhadap perilaku individu sebagai pembentuk goal congruance Anthony \& Govindarajan(2007) dalam Sidharta (2013). Menurut Hereath (2006) dalam Sidharta (2013), Nilai-nilai dan 
kepercayaan dari budaya organisasi memiliki peran penting dalam operasi pengendalian internal. menurut Robbins (2008) budaya berfungsi sebagai pembentuk rasa dan mekanisme pengendalian yang memberikan panduan dan bentuk prilaku serta sikap karyawan.

Menurut Liyanarachchi (2009) menunjukkan bahwa level penalaran moral individu akan mempengaruhi prilaku etis mereka. Moral adalah hal-hal yang sesuai dengan ide-ide yang umum diterima tentang tindakan manusia, mana yang baik, mana yang tidak baik dan mana yang wajar ataupun tidak wajar. Semakin manusia tidak memiliki moral semakin memungkinkan untuk terjadinya kecurangan dalam suatu hal. Menurut Udayani dan Sari (2017). Orang dengan level penalaran moral yang rendah berperilaku berbeda dengan orang yang memiliki level penalaran moral yanG tinggi ketika menghadapi dilema etika. Dalam tindakannya, orang yang memiliki level penalaran moral yang rendah cenderung akan melakukan hal - hal yang menguntungkan dirinya sendiri dan menghindari hal-hal yang akan menimbulkan sanksi hukum.

Pada penelitian ini peneliti bertujuan untuk menguji secara empiris pengaruh pengendalian internal, budaya organisasi, dan moralitas pada kecenderungan kecurangan (fraud) di LPD se-Kabupaten Gianyar. Penelitian ini diharpakan dapat berkontribusi dalam memberikan sumbangan pemikiran dalam pengembangan ilmu khususnya mengenai fraud dan dapat digunakan untuk membantu memecahkan berbagai masalah yang terkait serta dapat menjadi tambahan referensi bagi penelitian selanjutnya. Bagi peneliti selanjutnya, penelitian ini diharapkan memberikan 
ISSN: 2302-8556

kontribusi berupa penambahan pengetahuan mengenai fraud khususnya dalam operasional LPD. Bagi objek penelitian diharapkan dapat bermanfaat bagi pengelola dalam mencegah terjadinya kecurangan (fraud).

Berdasarkan Fraud Triangle Theory terdapat 3 faktor utama yang menyebabkan seseorang melakukan kecurangan. Ketiga faktor tersebut digambarkan sebagai segitiga kecurangan (fraud triangle). Dalam teori ini ketiga hal yang mendorong terjadinya kecurangan yakni, kesempatan (opportunity), tekanan (pressure), dan rasionalisasi (rationalization). Fraud Triangle Theory digunakan pada penelitian ini dikarenakan teori ini menjelaskan pentingnya suatu instansi meminimalkan kesempatan yang tersedia untuk melakukan kecurangan, dimana kesempatan dapat diminimalisir oleh Pengendalian Internal yang baik. Selain itu, salah satu faktor yakni, rasionalisasi sangat erat kaitannya dengan variabel moralitas karena apabila moralitas seorang karyawan dikategorikan baik maka akan kecil kemungkinan bagi karyawan tersebut untuk mencari alasan atau pembenaran untuk melakukan kegiatan yang mengindikasikan kecurangan. Selain itu, faktor tekanan yang berupa tekanan emosional yakni seperti kecemburuan, iri hati, gengsi, jabatan dapat ditekan dengan budaya organisasi yang baik. Budaya organisasi merupakan kesamaan nilai nilai yang dianut dalam suatu instansi dari atasan sampai bawahan. Sehingga, dengan kesamaan nilai yang dianut akan meminimalisir kemungkinan terjadinya sikap yang memperburuk kekompakan dalam organisasi. Dengan budaya organisasi yang baik maka akan terbentuk perilaku organisasi yang baik yakni, memiliki sense of belonging (rasa memiliki) terhadap instansi serta sense of identity (rasa bangga menjadi bagian dari instansi). 
Menurut Tunggal (2011), Kesempatan atau peluang adalah situasi yang membuka kesempatan bagi manajemen atau pegawai yang memungkinkan terjadinya kecurangan. Kesempatan mungkin saja disebabkan oleh pengendalian internal yang lemah, manajemen yang kurang baik dalam melakukan pengawasan, sikap apatis, atau penggunaan posisi yang mempermudah kecurangan bagi kepentingan pribadi. Pengendalian internal yang longgar dan pengawasan yang kurang dalam suatu perusahaan dapat memicu dan memperbesar kesempatan karyawan untuk melakukan kecurangan. Menurut Cressey (1953) dalam Tuanakotta (2007), pelaku kecurangan selalu memiliki pengetahuan dan kesempatan untuk melakukan tindakan agar tidak terdeteksi.

Menurut Tunggal (2011), Tekanan adalah dorongan orang untuk melakukan kecurangan. Karyawan mungkin merasa mendapat tekanan untuk melakukan kecurangan karena adanya kebutuhan atau masalah finansial. Menurut Dewi (2014), Faktor ekonomi, alasan emosional (iri/ cemburu, balas dendam, kekuasaan, gengsi), nilai (values) dan karena dorongan keserakahan adalah beberapa hal yang menimbulkan tekanan untuk melakukan fraud.

Menurut Dewi (2014), Rasionalisasi ditunjukkan saat pelaku mencari pembenaran sebelum melakukan kejahatan, bukan sesudah melakukan tindakan tersebut. Rasionalisasi merupakan bagian fraud triangle yang paling sulit untuk diukur. Bagi mereka yang umumnya tidak jujur maka akan lebih mudah merasionalisasi kecurangan. Bagi mereka dengan standar moral yang lebih tinggi, mungkin tidak begitu mudah. Pelaku kecurangan selalu mencari pembenaran rasional untuk membenarkan 
ISSN: 2302-8556

perbuatannya. Rasionalisasi menyebabkan pelaku kecurangan mencari pembenaran atas perbuatannya.

Jensen dan Meckling (1976) mendefinisikan hubungan keagenan sebagai kontrak antara satu orang atau lebih yang bertindak sebagai prinsipal (yaitu pemegang saham) yang menunjuk orang lain sebagai agen (yaitu manager) untuk melakukan jasa untuk kepentingan prinsipal termasuk mendelegasikan kekuasaan dalam pembuatan keputusan. Dalam penelitiannya juga dijelaskan bahwa dalam teori agensi terdapat Agency problem yang akan terjadi bila proporsi kepemilikan manajer atas saham perusahaan kurang dari 100\% sehingga manajer cenderung bertindak untuk mengejar kepentingan dirinya dan sudah tidak berdasar memaksimalisasi nilai dalam pengambilan keputusan pendanaan.

Menurut Eisenhardt (1989), ada tiga jenis asumsi yang menjadi landasan teori keagenan, yakni asumsi tentang sifat manusia, asumsi keorganisasian, dan asumsi informasi. Asumsi sifat manusia menekankan pada manusia memiliki sifat mementingkan diri sendiri (self interest), memiliki keterbatasan rasionalitas (bounded rasionality), dan tidak menyukai risiko (risk aversion). Asumsi keorganisasian adalah konflik antar anggota organisasi, efisiensi sebagai kriteria produktifitas, dan adanya asimetri informasi antara principal dan agen. Asumsi informasi adalah bahwa informasi sebagai barang komoditi yang bias diperjualbelikan.

Alasan digunakkannya Agency Theory dalam penelitian ini adalah adanya asumsi bahwa manajer dalam suatu perusahaan lebih banyak mengetahui informasi internal suatu perusahaan dibandingkan pemilik maka, akan terjadi kondisi 
ketidakseimbangan informasi antara manajer dan pemegang saham. Hal ini tentunya dapat menimbulkan konflik keagenan dimana pemegang saham memiliki kepentingan untuk memperoleh laba, sedangkan manajer juga memiliki keinginan untuk memperoleh kepuasan berupa kompensasi keuangan yang semakin besar, dalam hal ini, manajer yang lebih banyak mengetahui informasi internal, tentunya dapat dengan mudah untuk mengambil keputusan yang tidak menguntungkan bagi pihak pemegang saham namun menguntungkan bagi pihak manajer. Dalam teori agensi ini, manajer adalah pihak pengurus LPD dan pemegang saham adalah Desa Pekraman tempat LPD didirikan. Dengan adanya ketidakseimbangan informasi yang diperoleh maka akan membuka peluang terjadinya kecurangan. Hal ini dapat diminimalkan dengan Pengendalian Internal yang baik. Pengendalian Internal yang baik diharapkan mampu mengurangi adanya perilaku menyimpang dalam sistem pelaporan, termasuk adanya kecurangan akuntansi.

Menurut Tunggal (2011), Perusahaan-perusahaan yang melaksanakan pengendalian internal dalam perusahaan tentu akan membantu mereka dengan mudah mengecek kecurangan yang terjadi, dan pada akhirnya akan mudah mendeteksi kecurangan secara dini. Penelitian Saputra (2015) menyatakan bahwa pengendalian internal berpengaruh negatif terhadap kecurangan (fraud) pada LPD di Kabupaten Buleleng Bagian Timur. Demikian juga dengan Penelitian Zainal (2013) yang menyimpulkan efektivitas pengendalian intern berpengaruh signifikan negatif terhadap kecurangan akuntansi. Adinda (2015) juga menyatakan adanya pengaruh negatif dari keefektifan pengendalian internal terhadap kecurangan (fraud) di sektor pemerintahan. 
ISSN: 2302-8556

Hasil ini diperkuat oleh pendapat Coram (2008) yang menyatakan bahwa organisasi yang memiliki fungsi audit internal akan lebih dapat mendeteksi kecurangan akuntansi. Hal ini dikarenakan pengendalian internal yang baik akan menurunkan tingkat kecenderungan akuntansi yang mungkin terjadi.

Pengaruh pengendalian internal pada kecenderungan kecurangan kembali dipertegas oleh Fawzi (2011) yang menyatakan bahwa, Kecenderungan kecurangan (fraud) dipengaruhi oleh ada atau tidaknya peluang untuk melakukan hal tersebut. Peluang yang besar membuat kecenderungan kecurangan (fraud) lebih sering terjadi. Peluang tersebut dapat dikurangi dengan pengendalian internal yang baik. Pengendalian internal yang baik dapat mengurangi atau bahkan menutup peluang untuk melakuakan kecenderungan kecurangan akuntansi. Berdasarkan uraian tersebut maka disusun hipotesis yaitu :

$\mathrm{H}_{1}$ : Pengendalian Internal berpengaruh negatif pada Kecenderungan Kecurangan (fraud).

Budaya organisasi merupakan norma-norma, nilai, asumsi, kepercayaan, kebiasaan yang dibuat dalam suatu organisasi dan disetujui oleh semua anggota organisasi sebagai pedoman atau acuan dalam organisasi dalam melakukan aktivitasnya baik yang diperuntukkan bagi karyawan maupun untuk kepentingan orang lain. Dihubungkan dengan permasalahan kecurangan, salah satu faktor yang bisa mencegah kecurangan menurut Arens (2008) adalah budaya yang jujur dan etika yang tinggi. Menurut Ekayanti (2017), Semakin baiknya budaya organisasi yang diterapkan maka semakin baik pula efektivitas pengendalian intern, hal tersebut akan dapat 
meningkatkan perkembangan organisasi sehingga dapat meminimalisir kecenderungan kecurangan. Pada penelitian yang dilakukan Sulistiyowati (2007), menyatakan bahwa kultur organisasi berpengaruh terhadap persepsi aparatur pemerintah daerah tentang tindak korupsi. Selain itu penelitian yang dilakukan oleh Adinda (2015), mengatakan budaya organisasi berpengaruh negatif terhadap kecenderungan kecurangan (fraud). Berdasarkan uraian diatas maka disusun hipotesis yaitu :

$\mathrm{H}_{2}$ : Budaya Organisasi berpengaruh negatif pada Kecenderungan Kecurangan (fraud) Menurut Liyanarachchi (2009) menunjukkan bahwa level penalaran moral individu akan dipengaruhi prilaku etis mereka. Berdasarkan penelitian yang dilakukan Aranta (2013) menyatakan bahwa moralitas berpengaruh signifikan negatif terhadap kecenderungan kecurangan akuntansi. Hasil penelitian ini sama dengan yang dilakukan Tarigan (2016) dan Udayani (2017) yang menyatakan bahwa moralitas berpengaruh signifikan negatif terhadap kecenderungan kecurangan (fraud). Berdasarkan uraian di atas maka disusun hipotesis yaitu :

$\mathrm{H}_{3}$ : Moralitas berpengaruh negatif pada Kecenderungan Kecurangan (Fraud)

\section{METODE PENELITIAN}

Desain penelitian yang digunakan dalam penelitian ini adalah pendekatan kuantitatif berbentuk asosiatif, artinya penelitian ini dilakukan untuk mengetahui pengaruh variable pengendalian internal, budaya organisasi, dan moralitas pada kecenderungan kecurangan (fraud). Penelitian ini dilaksanakan di Kabupaten Gianyar, Provinsi Bali dengan subjek penelitian Kepala LPD yang terdapat di Kabupaten Gianyar. Obyek dalam penelitian ini adalah kecenderungan kecurangan akuntansi pada LPD Se- 
ISSN: 2302-8556

Kabupaten Gianyar yang dijelaskan oleh Pengendalian Internal, Budaya Organisasi, dan Moralitas.

Variabel-variabel yang dianalisis dalam penelitian ini adalah variabel bebas dan variabel terikat. Variabel terikat atau variable dependen merupakan variabel yang dipengaruhi oleh variable bebas atau variabel independent. Variabel terikat dalam penelitian ini adalah Kecenderungan Kecurangan (Fraud). Kecenderungan Kecurangan merupakan kesengajaan melakukan tindakan merugikan untuk memperoleh keuntungan dengan cara memanipulasi sehingga melaporkan laporan keuangan tidak sesuai keadaan sebenarnya. Variabel kecenderungan kecurangan diukur dengan instrumen penelitian yang dikembangkan oleh Shintadevi (2015).

Indikator yang digunakan adalah kecenderungan untuk melakukan manipulasi, pemalsuan, atau perubahan catatan akuntansi atau dokumen pendukungnya, kecenderungan untuk melakukan penyajian yang salah satu atau penghilangan peristiwa, transaksi, atau informasi yang signifikan dari laporan keuangan, kecurangan untuk melakukan salah menerapkan prinsip akuntansi secara sengaja, kecenderungan untuk melakukan penyajian laporan keuangan yang salah akibat perlakuan yang tidak semestinya terhadap aktiva dan disertai dengan catatan atau dokumen palsu dan dapat menyangkut satu atau lebih individu di antara manajemen, karyawan, atau pihak ketiga.

Variabel independent pertama dalam penelitian ini adalah Pengendalian Internal $\left(\mathrm{X}_{1}\right)$. Menurut Abdul Halim (2003:197) dalam Prekanida (2015) pengendalian internal merupakan rangkaian proses yang dijalankan entitas, yang mana proses tersebut mencakup berbagai kebijakan dan prosedur sistematis, bervariasi dan memiliki 
tujuan utama untuk menjaga keandalan pelaporan keuangan entitas, menjaga efektif dan efisiensi operasi yang dijalankan, dan menjaga kepatuhan hukum dan peraturan yang berlaku. Pengendalian internal juga diartikan sebagai kontrol dalam suatu organisasi yang bertujuan untuk mengarahkan dan mengawasi sumber daya organisasi yang diharapkan dapat membantu organisasi dalam mencapai tujuannya. Pengendalian Internal diukur menggunakan lima indikator antara lain lingkungan pengendalian, penilaian resiko, aktivitas pengendalian, informasi dan komunikasi dan pemonitoran yang dikembangkan oleh penelitian Pinatih (2015) dengan menggunakan skala likert 1 -5 . Variabel ini diukur dengan 8 buah pertanyaan dalam kuesioner.

Variabel independent kedua dalam penelitian ini adalah Budaya Organisasi $\left(\mathrm{X}_{2}\right)$. Budaya organisasi adalah nilai-nilai dari keyakinan yang dimiliki oleh anggota organisasi yang dituangkan ke dalam bentuk norma-norma perilaku para individu kelompok organisasi ditempat individu tersebut bekerja (Hofstede, 1990). Pengukuran variabel budaya organisasi menggunakan 15 buah pertanyaan yang diambil dari penelitian Gunawan (2014) yang diukur dengan skala likert 1 - 5. Indikator dalam pengukuran variabel Budaya Organisasi yakni, Inisiatif Individual, Pengarahan, Dukungan Manajemen, dan Kontrol.

Variabel independent ketiga dalam penelitian ini adalah Moralitas $\left(\mathrm{X}_{3}\right)$. Moralitas adalah sifat moral atau keseluruhan asas dan nilai yang berkenaan dengan baik dan buruk. Orang dengan level penalaran moral yang rendah berperilaku berbeda dengan orang yang memiliki level penalaran moral yang tinggi ketika menghadapi dilema etika. Level penalaran moral individu akan mempengaruhi perilaku etis 
ISSN: 2302-8556

mereka. Berdasarkan penelitian Udayani (2017) Moralitas individu diukur dengan tiga indikator antara lain, pra-konvensional, konvensional, dan post-konvensional. dengan menggunakan skala likert $1-5$. Setiap instrument pertanyaan mewakili sebuah indikator yang mengukur setiap tahapan moralitas individu.

Jenis data yang digunakan dalam penelitian ini adalah data kuantitatif. Menurut Sugiyono (2013), Data kuantitatif adalah data dalam bentuk angka-angka atau data kualitatif yang dirubah ke dalam angka. Data kuantitatif dalam penelitian ini beupa hasil dari olahan kuesioner yang disebarkan oleh peneliti ke setiap Ketua LPD di kabupaten Gianyar. Sumber data yang digunakan dalam penelitian ini adalah data primer yaitu, data yang diperoleh langsung dari sumbernya. Data primer dalam penelitian ini berupa jawaban responden atas kuesioner yang dikumpulkan dari Ketua LPD di kabupaten Gianyar.

Populasi adalah wilayah generalisasi yang terdiri atas objek atau subjek yang mempunyai kualitas dan karakteristik tertentu yang ditetapkan oleh peneliti untuk dipelajari dan kemudian ditarik kesimpulannya (Sugiyono, 2013). Penelitian ini dilaksanakan di Seluruh LPD di Kabupaten Gianyar berdasarkan data LPLPD Kabupaten Gianyar yaitu sebanyak 270 LPD. Sampel dalam penelitian ini adalah LPD yang masih aktif dan tercatat dalam LPLPD Kabupaten Gianyar. Metode pengambilan sampel dalam penelitian ini yaitu probability sampling dengan metode proportionate stratified random sampling, jadi dari total 270 LPD yang tercatat dalam LPLPD Kabupaten Gianyar digunakan rumus slovin untuk menentukan proporsi sampelnya. Responden dalam penelitian ini yaitu masing masing LPD sebanyak 1 orang yakni 
Ketua LPD dikarenakan memiliki tanggungjawab dan mengetahui secara detail mengenai operasional LPD.

Metode pengumpulan data dalam penelitian ini menggunakan kuesioner. Kuesioner merupakan teknik pengumpulan data yang dilakukan dengan cara memberikan seperangkat pertanyaan atau pernyataan tertulis kepada responden untuk dijawabnya, Sugiyono (2013). Kuesioner yang akan dijawab oleh responden dalam penelitian ini berisi pertanyaan maupun pernyataan yang berhubungan dengan pengaruh pengendalian internal, budaya organisasi, dan moralitas pada kecenderungan kecurangan (fraud) di LPD se-Kabupaten Gianyar. Teknik analisis data yang digunakan dalam penelitian ini adalah teknik analisis regresi linear berganda, yaitu untuk mengetahui ketergantungan variabel terikat terhadap variabel bebas, serta untuk mengetahui ketergantungan variabel terikat dengan variabel variabel bebas. Penelitian ini dilakukan untuk mengetahui pengaruh pengendalian internal, budaya organisasi, dan moralitas pada kecenderungan kecurangan (fraud). Selain itu, penelitian ini juga disertai dengan uji validitas, uji reliabilitas, uji asumsi klasik, uji koefisien determinasi, uji siginifikansi F dan uji parsial (uji t).

\section{HASIL DAN PEMBAHASAN}

Berdasarkan hasil penelitian dan penyebaran kuesioner jumlah responden sebanyak 73 orang. Berdasarkan tabel 2, dapat dilihat bahwa variabel pengendalian internal $\left(\mathrm{X}_{1}\right)$ memiliki nilai minimum sebesar 30, nilai maksimum sebesar 40, mean sebesar 35, 29 dan standar deviasi sebesar 2,595. Ini berarti bahwa terjadi perbedaan nilai pengendalian internal yang diteliti terhadap nilai rata-ratanya sebesar 2,595. Variabel 
ISSN: 2302-8556

budaya organisasi $\left(\mathrm{X}_{2}\right)$ memiliki nilai minimum sebesar 59 , nilai maksimum 75 , mean sebesar 66,93, dan standar deviasi sebesar 3,421. Ini berarti terjadi perbedaan nilai budaya organisasi yang diteliti terhadap nilai rata-ratanya sebesar 3,421. Variabel moralitas $\left(\mathrm{X}_{3}\right)$ memiliki nilai minimum sebesar 10, nilai maksimum sebesar 15 , mean sebesar 12,70, dan standar deviasi sebesar 1,187. Ini berarti bahwa terjadi perbedaan nilai moralitas yang diteliti terhadap nilai rata-ratanya sebesar 1,187.

Tabel 2.

Hasil Analisis Statistik Deskriptif

\begin{tabular}{llllll}
\hline & N & Minimum & Maximum & Mean & Std.Deviation \\
\hline Pengendalian Internal & 73 & 30 & 40 & 35,29 & 2,595 \\
Budaya Organisasi & 73 & 59 & 75 & 66,93 & 3,421 \\
Moralitas & 73 & 10 & 15 & 12,70 & 1,187 \\
Kecenderungan & & & & & \\
Kecurangan (Fraud) & 73 & 15 & 36 & 24,04 & 4,653 \\
Sumber: Data diolah, 2018 & & & & &
\end{tabular}

Variabel kecenderungan kecurangan (fraud) (Y) memiliki nilai minimum sebesar 15, nilai maksimum sebesar 36, mean sebesar 24,04, dan standar deviasi sebesar 4,653. Ini berarti bahwa terjadi perbedaan nilai kecenderungan kecurangan (fraud) yang diteliti terhadap nilai rata-ratanya sebesar 4,653.

Uji validitas dilakukan untuk mengetahui sejauh mana alat ukur tersebut dapat digunakan untuk mengukur apa yang seharusnya diukur (Sugiyono, 2013). Suatu instrumen dikatakan valid apabila nilai Pearson correlation terhadap skor total di atas 0,3 (Sugiyono, 2013). Hasil uji validitas menunjukkan bahwa seluruh variabel memeliki nilai koefisien korelasi dengan skor total seluruh item pernyataan lebih besar dari 0,30 . Hal ini menunjukkan bahwa butir-butir pernyataan dalam instrumen penelitian tersebut valid. 
Uji reliabilitas digunakan untuk mengukur apakah instrumen yang digunakan beberapa kali mengukur objek yang sama, akan menghasilkan data yang sama. Instrumen dinyatakan reliabel apabila menghasilkan data yang sama ketika digunakan berulang kali (Sugiyono, 2013). Hasil instrument memiliki nilai Alpha Cronbach yang lebih besar dari 0,60 maka instrumen yang digunakan dikatakan reliabel. Berdasrkan hasil uji reliabilitas yang disajikan dalam tabel 3, dapat disimpulkan variabel-variabel yang digunakan dalam penelitin ini reliabel yang dapat dilihat dari nilai Cronbach's Alpha $>0,60$. Berdasarkan hasil uji reliabilitas yang disajikan dalam tabel 3, dapat disimpulkan variabel-variabel yang digunakan dalam peneltian ini reliabel, sehingga layak digunakan untuk menjadi alat ukur instrument kuesioner dalam penelitian ini.

\section{Tabel 3.}

Hasil Uji Reliabilitas

\begin{tabular}{clcc}
\hline No & \multicolumn{1}{c}{ Variabel } & Cronbach's Alpha & Keterangan \\
\hline 1 & Pengendalian Internal (X1) & 0,772 & Reliabel \\
2 & Budaya Organisasi (X2) & 0,775 & Reliabel \\
3 & Moralitas (X3) & 0,745 & Reliabel \\
4 & Kecenderungan Kecurangan & 0,781 & Reliabel \\
& $($ Fraud $)(Y)$ & & \\
\hline
\end{tabular}

Sumber : Data diolah, 2018

Hasil uji reliabilitas yang disajikan dalam tabel 3, menunjukkan bahwa seluruh instrument penelitian memiiki koefisien Cronbach's Alpha lebih dari 0,60. Hal ini menunjukkan bahwa semua instrument dapat digunakan untuk melakukan penelitian.

\section{Tabel 4.}

Hasil Uji Normalitas

\begin{tabular}{lcccc}
\hline & $\begin{array}{c}\text { Pengendalian } \\
\text { Internal }\end{array}$ & $\begin{array}{c}\text { Budaya } \\
\text { Organisasi }\end{array}$ & Moralitas & $\begin{array}{c}\text { Kecenderungan } \\
\text { Kecurangan } \\
\text { (Fraud) }\end{array}$ \\
\hline $\mathrm{N}$ & 73 & 73 & 73 & 73 \\
$\begin{array}{l}\text { Asymp. Sig. (2- } \\
\text { tailed) }\end{array}$ & 0,197 & 0,608 & 0,072 & 0,382 \\
\hline
\end{tabular}

Sumber: Data diolah, 2018 
Salah satu asumsi yang harus dipenuhi dalam penelitian yang menggunakan statistik parametrk dengan model analisis regresi linear berganda adalah uji asumsi klasik. Hasil uji Kolmogorov-Smirnov Test yang disajikan pada Tabel 4, menunjukkan bahwa nilai signifikansi variabel Pengendalian Internal $\left(\mathrm{X}_{1}\right)$ sebesar 0,197 , budaya organisasi $\left(\mathrm{X}_{2}\right)$ sebesar 0,608 , moralitas $\left(\mathrm{X}_{3}\right)$ sebesar 0,072, dan kecenderungan kecurangan (fraud) (Y) sebesar 0,382 artinya lebih besar dari level of significance 0,05. Hal ini menunjukkan seluruh variabel dalam penelitian ini berdistribusi normal.

Tabel 5.

Hasil Uji Multikolinearitas

\begin{tabular}{lcc}
\hline \multirow{2}{*}{ Variabel } & \multicolumn{2}{c}{ Collinearity Statistics } \\
\cline { 2 - 3 } & Tolerance & VIF \\
\hline Pengendalian Internal (X1) & 0,339 & 2,947 \\
Budaya Organisasi (X2) & 0,376 & 2,660 \\
Moralitas (X3) & 0,319 & 3,136 \\
\hline
\end{tabular}

Sumber : Data diolah, 2018

Hasil uji multikolinieritas yang disajikan pada tabel 5, menunjukkan variabel bebas dalam regresi tidak saling berkorelasi. Diperoleh nilai tolerance sebesar 0,339> 0,01 dan VIF sebesar 2,947 < 10 , pada variabel Budaya Organisasi didapatkan nilai tolerance sebesar $0,376>0,01$ dan VIF sebesar 2,660 < 10 , dan pada variabel Moralitas didapatkan nilai tolerance sebesar 0,319>0,01 dan VIF sebesar 3,136<10. Sehingga dapat disimpulkan semua variabel bebas dari gejala multikoloniearitas.

\section{Tabel 6.}

\section{Hasil Uji Heterokedastisitas}

\begin{tabular}{lcl}
\hline \multicolumn{1}{c}{ Variabel } & Sig. & Keterangan \\
\hline Pengendalian Internal & 0,580 & Bebas heterokedastisitas \\
Budaya Organisasi & 0,262 & Bebas heterokedastisitas \\
Moralitas & 0,151 & Bebas heterokedastisitas \\
\hline Sumber $:$ Data diolah 2018 &
\end{tabular}

Sumber : Data diolah, 2018 
Uji heteroskedastisitas dilakukan untuk menguji apakah dalam model regresi terjadi ketidaksamaan variance dari residual pengamatan satu ke pengamatan lainnya. Berdsarkan hasil uji SPSS terhadap variabel pengendalian internal didapatkan nilai sig. sebesar 0,580 >0,05, terhadap variabel budaya organisasi didapatkan nilai sig. sebesar $0,262>0,05$, dan terhadap variabel moralitas didapatkan nilai sig. sebesar $0,151>$ 0,05 sehingga dapat disimpulkan bahwa tidak terjadi gejala heterokedastisitas. Hasil uji heterokedastisitas disajikan pada tabel 6.

Analisis regresi linear berganda adalah model yang digunakan untuk menganalisis pengaruh lebih dari satu variabel independen terhadap satu variabel dependen. Uji ini dilakukan untuk mengetahui besarnya pengaruh Pengendalian Internal (X1), Budaya Organisasi (X2), Moralitas (X3) pada Kecenderungan Kecurangan (fraud) (Y).

Tabel 7.

Hasil Analisis Regresi Linear Berganda

\begin{tabular}{|c|c|c|c|c|c|}
\hline \multirow[t]{2}{*}{ Model } & \multicolumn{2}{|c|}{ Unstandardized Coefficients } & \multirow{2}{*}{$\begin{array}{c}\begin{array}{c}\text { Standardized } \\
\text { Coefficients }\end{array} \\
\text { Beta } \\
\end{array}$} & \multirow[t]{2}{*}{$\mathbf{t}$} & \multirow[t]{2}{*}{ Sig. } \\
\hline & B & Std. Error & & & \\
\hline (Constant) & 84,241 & 7,081 & & 11,897 & 0,000 \\
\hline $\mathrm{X}_{1}$ & $-0,486$ & 0,227 & $-0,271$ & $-2,144$ & 0,036 \\
\hline $\mathrm{X}_{2}$ & $-0,446$ & 0,163 & $-0,328$ & $-2,728$ & 0,008 \\
\hline$X_{3}$ & $-1,042$ & 0,511 & $-0,266$ & $-2,038$ & 0,045 \\
\hline Adjusted $\mathrm{R}^{2}$ & 0,610 & & & & \\
\hline F Hitung & 38,493 & & & & \\
\hline Signifikansi F & $0,000^{\mathrm{b}}$ & & & & \\
\hline
\end{tabular}

Hasil dari analisis regresi linear berganda ini disajikan pada Tabel 4.7. Berdasarkan hasil analisis regresi linear berganda pada Tabel 4.7, maka dapat dirumuskan persamaan regresinya sebagai berikut: 
$\mathrm{Y}=84,241-0,486 \mathrm{X}_{1}-0,446 \mathrm{X}_{2}-1,042 \mathrm{X}_{3}$

Nilai konstanta sebesar 84,241 artinya apabila tidak ada variabel pengendalian internal $\left(\mathrm{X}_{1}\right)$, budaya organisasi $\left(\mathrm{X}_{2}\right)$, moralitas $\left(\mathrm{X}_{3}\right)$, maka kecenderungan kecurangan (fraud) (Y) meningkat. Nilai koefisien regresi Pengendalian Internal $\left(\mathrm{X}_{1}\right)$ sebesar 0,486. Hal ini berarti bahwa apabila variabel pengendalian internal $\left(\mathrm{X}_{1}\right)$ meningkat, maka akan mengakibatkan penurunan pada Kecenderungan Kecurangan (fraud) dengan asumsi variabel bebas lainnya dianggap konstan.

Nilai koefisien regresi Budaya Organisasi $\left(\mathrm{X}_{2}\right)$ sebesar $-0,446$. Hal ini berarti bahwa apabila variabel budaya organisasi $\left(\mathrm{X}_{2}\right)$ meningkat, maka akan mengakibatkan penurunan pada Kecenderungan Kecurangan (fraud) dengan asumsi variabel bebas lainnya dianggap konstan.

Nilai koefisien regresi Moralitas $\left(\mathrm{X}_{3}\right)$ sebesar $-1,402$. Hal ini berarti bahwa apabila variabel moralitas $\left(\mathrm{X}_{3}\right)$ meningkat, maka akan mengakibatkan penurunan pada Kecenderungan Kecurangan (fraud) dengan asumsi variabel bebas lainnya dianggap konstan.

Koefisien determinasi $\left(\mathrm{R}^{2}\right)$ bertujuan untuk mengukur seberapa jauh kemampuan model dalam menerangkan variasi variabel dependen. Besarnya nilai koefisien determinasi ditunjukkan dengan nilai Adjusted $R^{2}$ sebesar 0,610. Hasil ini berarti bahwa $61 \%$ variasi besarnya Kecenderungan Kecurangan (fraud) dapat dijelaskan oleh Pengendalian Internal, Budaya Organisasi, dan Moralitas. Sedangkan sisanya sebesar $39 \%$ dipengaruhi oleh variabel-variabel lain diluar model penelitian. 
Sebelum dilakukan pengujian hipotesis, satu hal yang perlu diperhatikan adalah kelayakan model penelitian yang dilakukan dengan uji F untuk mengetahui apakah semua variabel independen yang dimasukkan dalam model mempunyai pengaruh secara bersamasama pada variabel dependen. Jika nilai sig $\mathrm{F}<\alpha=0,05$ berarti variabel independen memengaruhi variabel dependen. Variabel independen layak digunakan untuk memprediksi variabel dependen, sehingga pembuktian hipotesis dapat dilanjutkan.

Hasil analisis kelayakan model $\mathrm{F}$ menunjukkan bahwa nilai $\mathrm{F}$ hitung sebesar 38,493 dengan nilai signifikansi uji $\mathrm{F}$ yaitu sebesar 0,000 yang lebih kecil dari 0,05 . Hasil ini memberikan makna bahwa variabel Pengendalian Internal, Budaya Organisasi, dan Moralitas secara bersama-sama (simultan) berpengaruh pada Kecenderungan Kecurangan (fraud) artinya kedua variabel independen mampu menjelaskan Kecenderungan Kecurangan di LPD se-Kabupaten Gianyar.

Nilai t hitung pada variabel pengendalian internal adalah sebesar -2,144 dengan tingkat signifikansi 0,036. Dengan menggunakan batas signifikansi 0,05 maka signifikansi tersebut dibawah taraf $5 \%$ yang artinya $\mathrm{H}_{0}$ ditolak dan $\mathrm{H}_{1}$ diterima. Hal ini menunjukkan bahwa Pengendalian Internal berpengaruh negatif pada Kecenderungan Kecurangan (Fraud).

Peluang yang besar membuat kecenderungan kecurangan (fraud) lebih sering terjadi. Peluang tersebut dapat dikurangi dengan pengendalian internal yang baik. Pengendalian Internal yang baik dapat mengurangi atau bahkan menutup peluang terhadap kecenderungan kecurangan (fraud). Hasil penelitian ini sejalan dengan penelitian yang dilakukan Fawzi (2011) dan Zainal (2013) yang menunjukkan 
pengendalian internal berpengaruh negatif pada kecenderungan kecurangan. Hasil ini juga didukung oleh penelitian Adinda (2015) dan Udayani (2017) yang menemukan bahwa terdapat pengaruh negatif pengendalian internal terhadap kecenderungan kecurangan (fraud).

Nilai t hitung pada variabel budaya organisasi adalah sebesar $-2,728$ dengan tingkat signifikansi 0,008. Dengan menggunakan batas signifikansi 0,05 maka signifikansi tersebut dibawah taraf $5 \%$ yang artinya $\mathrm{H}_{0}$ ditolak dan $\mathrm{H}_{2}$ diterima. Ini menunjukkan bahwa variabel budaya organisasi berpengaruh negatif pada kecenderungan kecurangan (fraud).

Budaya organisasi merupakan norma-norma, nilai, asumsi, kepercayaan, kebiasaan yang dibuat dalam suatu organisasi dan disetujui oleh semua anggota organisasi sebagai pedoman atau acuan dalam organisasi dalam melakukan aktivitasnya baik yang diperuntukkan bagi karyawan maupun untuk kepentingan orang lain. Organisasi bertanggung jawab untuk menerapkan budaya organisasi yang baik dalam perusahaan agar tindakan kecurangan bisa diminimalkan. Budaya organisasi yang baik dapat meningkatkan rasa memiliki karyawan terhadap perusahaan sehingga akan meminimalkan tindak kecurangan yang mungkin terjadi. Hasil penelitian ini sejalan dengan penelitian Adinda (2015) yang menyatakan bahwa budaya organisasi berpengaruh negatif terhadap kecenderungan kecurangan (fraud).

Nilai t hitung pada variabel moralitas adalah sebesar -2,038 dengan tingkat signifikansi 0,045. Dengan menggunakan batas signifikansi 0,05 maka signifikansi 
tersebut dibawah $5 \%$ yang artinya $\mathrm{H}_{0}$ ditolak dan $\mathrm{H}_{3}$ diterima. Ini menunjukkan bahwa variabel moralitas berpengaruh negative pada kecenderungan kecurangan (fraud).

Moralitas merupakan salah satu faktor yang penting dalam timbulnya kecurangan. Adanya tingkah laku atau moral yang jelek atau tidak baik yang menjadikan seseorang atau aparat pemerintahan dapat melakukan tindakan kecurangan. Semakin tinggi tingkat penalaran moral seseorang, maka orang tersebut akan semakin mungkin melakukan hal yang benar dan minimal kemungkinan untuk melakukan kecurangan, begitu juga sebaliknya, semakin rendah penalaran moral seseorang, semakin mungkin melakukan hal yang tidak benar dan semakin memungkinkan untuk melakukan kecurangan. Hasil penelitian ini sejalan dengan penelitian Aranta (2013) dan Tarigan (2016) yang menyatakan bahwa moralitas berpengaruh signifikan negatif terhadap kecenderungan kecurangan. Hasil yang sama juga didapat Udayani (2017) yang menunjukkan pengaruh negatif moralitas terhadap kecenderungan kecurangan pada Villa di Kawasan Umalas.

\section{SIMPULAN}

Berdasarkan hasil penelitian dan pembahasan yang telah diungkapkan pada bab-bab sebelumnya maka dapat ditarik suatu simpulan bahwa Pengendalian Internal, Budaya Organisasi, dan Moralitas berpengaruh negatif pada Kecenderungan Kecurangan (fraud) di LPD se-Kabupaten Gianyar. Hal ini berarti semakin baik Pengendalian Internal, Budaya Organisasi dan Moralitas maka semakin kecil Kecenderungan Kecurangan (fraud) di LPD se-Kabupaten Gianyar. 
ISSN: 2302-8556

Saran yang dapat disimpulkan dari simpulan yang telah disampaikan adalah Peneliti selanjutnya diharapkan dapat meneliti dengan menggunakan metode observasi sehingga didapat gambaran yang lebih detail mengenai variabel yang sedang diteliti. Variabel yang digunakan dalam Penelitian ini hanya meliputi Pengendalian Internal, Budaya Organisasi, dan Moralitas dimana berdasarkan nilai koefisien determinasi hanya $61 \%$ pengaruhnya terhadap Kecenderungan Kecurangan (Fraud) dan 39\% sisanya masih belum diteliti. Peneliti selanjutnya diharapkan dapat meneliti variabel variabel lain yang berhubungan dengan Kecenderungan Kecurangan (Fraud) seperti Asimetri Informasi, Kepuasan Kerja, Ketaatan Aturan sehingga akan mendapatkan hasil yang lebih banyak dan lebih luas mengenai faktor-faktor yang mempengaruhi Kecenderungan Kecurangan (Fraud). Sampel yang digunakan dalam penelitian ini hanya pada LPD yang ada di Kabupaten Gianyar, sehingga belum mampu merepresentasikan semua LPD di seluruh Kabupaten/Kota di Bali. Untuk penelitian selanjutnya diharapkan memilih sampel LPD yang berada di Kabupaten/Kota lain di Bali sehingga lebih dapat menggambarkan pengaruh dari variabel-variabel penelitian ini pada koperasi di Bali.

\section{REFERENSI}

Adewale, Odunayo Hendry. 2014. Internal Control System: A Managerial Tool For Proper Accountability A Case Study of Nigeria Customs Service. European Scientific Journal. 10(13).

Adinda, Yanita Maya. 2015. Faktor Yang Mempengaruhi Terjadinya Kecurangan (Fraud) Di Sektor Pemerintahan Kabupaten Klaten. Accounting Analysis Journal Universitas Negeri Semarang, 4 (3), Hal. 7-9. 
Aranta, Zulia Petra. 2013. Pengaruh Moralitas Aparat dan Asimetri Informasi terhadap Kecenderungan Kecurangan Akuntansi (Studi Empiris Pemerintah Kota Sawahlunto). Jurnal Program Studi Akuntansi Universitas Negeri Padang, 3 (2), $11-15$.

Arens et al. 2008. Auditing dan Jasa Assurance Pendekatan Terintegrasi. Jakarta: Erlangga.

Badan Pemeriksa Keuangan Republik Indonesia (BPK RI), Peraturan No. 1 Tahun 2007 tentang Standar Pemeriksaan Keuangan.

Bali Antara News. 2017. Ketua LPD Belaluan Tersangka. Diunduh tanggal 20 Desember 2017, http://bali.antaranews.com

Bali Tribun. 2017. 150 LPD di Bali Dinyatakan Bangkrut. Diunduh tanggal 20 Desember 2017, http://balitribune.co.id

Bali Tribun News. 2015. Tertunduk Lesu dibui dalam Kasus Korupsi di LPD Kerta. Diunduh tanggal 20 Desember 2017, http://bali.tribunnews.com

Bali Post. 2017. Tiga Wanita Diadili Kasus Dugaan Korupsi LPD Suwat. Diunduh tanggal 20 Desember 2017, www.balipost.com

Coram, P., Glavovic, A., Ng, Juliana, dan Woodliff, David R. 2008. The Mortal Intensity of Reduced Audit Quality Acts. A Journal of Practice \& Theory. 19 (1), 127-149

Dewi, Gusti Ayu Ketut Rencana Sari. 2014. Pengaruh Moralitas Individu Dan Pengendalian Internal Pada Kecurangan Akuntansi (Studi Eksperimen Pada Pemerintah Daerah Provinsi Bali). Jurnal Ilmiah Akuntansi Universitas Pendidikan Ganesha, 1 (1), 77-92.

Dorminey, J., A.S. Fleming., M.J. Kranacher, dan R. A. Riley. 2011. Beyond The Fraud Triangle. Enchancing Deterrence of Economic Crimes. CPA Journal. 80 (7), 1723

Eisenhardt, Kathleem. 1989. Agency Theory: An Assesment and Review. Academy of Management Review. 13(1), 57-74. 
Ekayanti, Ni Wayan. Sujana, Edy. Wahyuni, Made Arie. 2017. Pengaruh Budaya Organisasi, Gaya Kepemimpinan, dan Pengalaman Kerja terhadap Efektivitas Sistem Pengendalian Intern pada Lembaga Perkreditan Desa (LPD) SeKecamatan Payangan Kabupaten Gianyar. E-Journal S1 Ak Universitas Pendidikan Ganesha, 7(1), 45-56.

Fawzi, Mohammad Glifandi Hari. 2011. Analisis Pengaruh Keefektifan Pengendalian Internal, Persepsi Kesesuaian Kompensasi, Moralitas Manajemen Terhadap Perilaku Tidak Etis dan Kecederungan Kecurangan Akuntansi. E-Journal Universitas Diponegoro, 7 (1), 45-96.

Ghozali, Imam. 2016. Aplikasi Analisis Multivariate dengan Program IBM SPSS 23. Edisi ke-8. Semarang: Badan Penerbit Universitas Diponegoro.

Glaser, Susan R. Zamanou, Sonia. Hacker Kenneth. 1987. Measuring and Interpreting Organizational Culture. Management Communication Quarterly 1987, 1 (1), 173-197.

Herath, S.K. 2006. A framework for management control research", Journal of Management Development, 26 (9), 896-915.

Hernandez, J. R. dan T. Groot. 2007. Corporate Fraud: Preventive Controls Which Lower Corporate Fraud. Amsterdam Research Centre in Accounting. 6 (18), 2456.

Hofstede G. Neuijen, B. Ohavy, DD, and Sanders G. 1990. "Measuring Organization Culture: A Qualitative and Quantitative Study across Twenty Cases". Administrative Science Quarterly, 35 (2), 286-316.

IAI. 2001. Standar Profesional Akuntan Publik. Jakarta: Salemba Empat.

Jensen \& Meckling. 1976. The Theory of The Firm: Manajerial Behavior, Agency Cost, and Ownership Structure. Journal of Financial and Economics. 3 (1), 305360.

Kohlberg, Lawrence. 1971. Stages of Moral Development. Diunduh tanggal 12 Desember 2017, https://pdfs.semanticscholar.org 
Kristiana, Wiwik Lepang. Wahyuni, Made Arie. Sujana, Edy. 2017. Pengaruh Sistem Pengendalian Intern, Kinerja Organisasi Dan Budaya Organisasi Terhadap Penerapan Good Corporate Governance (Studi Kasus Pada Lpd Se-Kecamatan Sukasada). E-journal S1 Ak Universitas Pendidikan Ganesha,E-journal S1 Ak Universitas Pendidikan Ganesha, 7(1), 35-57.

Liyanarachi, G. 2009. The Impact of Moral Reasoning and Retaliation on WhistleBlowing: New-Zealand Evidence. Journal of Business Ethics, 89, 37-57

Marcoulides, George A, dan Heck, Ronald H. 1993. Organizational Culture and Performance: Proposing and Testing a Model. Organization Science, 4(2), 209225

Nata Wirawan, I Gusti Putu. 2002. Cara Mudah Memahami Statistik 2 (Statistik Inferensia) Untuk Ekonomi dan Bisnis. Edisi Kedua. Denpasar: Keraras Emas.

Peraturan Daerah Provinsi Bali No. 3 Tahun 2017 tentang Lembaga Perkreditan Desa

Peraturan Pemerintah Republik Indonesia No. 8 Tahun 2006 tentang Pelaporan Keuangan dan Kinerja Instansi Pemerintahan.

Robbins, Stehen P. 2008. Perilaku Organisasi. Jilid II. Jakarta: Salemba Empat.

Saputra, Gede Krisna. Dharmawan, Nyoman Ari Surya. Purnamawati, I Gusti Ayu. 2015. Pengaruh Pengendalian Intern Kas, Implementasi Good Governance, dan Moralitas Individu terhadap Kecurangan (Fraud). E-journal S1 Ak Universitas Pendidikan Ganesha, 3(1), 78-105.

Shintadevi, Prekanida Farizqa. 2015. Pengaruh Keefektifan Pengendalian Internal, Ketaatan Aturan Akuntansi Dan Kesesuaian Kompensasi Terhadap Kecenderungan Kecurangan Akuntansi Dengan Perilaku Tidak Etis Sebagai Variabel Intervening pada Universitas Negeri Yogyakarta. Jurnal Nominal, 4 (2), 122-124.

Sidharta, Eka Ananta. 2013. Perubahan Budaya Organisasi Berdampak Kepada Perubahan Management Control System. Jurnal Akuntansi Aktual, 2 (1), 34-45. 
ISSN: 2302-8556

E-Jurnal Akuntansi Universitas Udayana

Vol.25.3.Desember (2018): 2155- 2184

Smith, J. Reed, Samuel L. Tiras \& Sansakrit S. Vichitlekarn. (1997). "The Interaction Between Internal Control Assessment and Substantive Testing in Audits for Fraud". Contemporary Accounting Research - Draft : October 1997, 17 (2), 327356.

Subramaniam dan Rae. 2008. Quality of Internal Control Procedures Antecedents and Moderating Effect on Organizational Justice and Employee Fraud. Managerial Auditing Journal, 23 (2), 104 - 124.

Sugiyono. 2013. Metode Penelitian Kualitatif dan R\&D. Bandung: Alfabeta.

Sulistiyowati, Firma. 2007. Pengaruh Kepuasan Gaji dan Kultur Organisasi Terhadap Persepsi Aparatur Pemerintah Daerah Tentang Tindak Korupsi. Jurnal Akuntansi dan Auditing Indonesia, 11 (1), 47-66.

Tarigan, Laurensia Br. 2016. Pengaruh Moralitas Individu, Asimetri Informasi, Efektivitas Pengendalian Internal dan Ketaatan Aturan Akuntansi terhadap Kecenderungan Kecurangan Akuntansi (Studi pada BUMD Provinsi Riau). JOM Fekom, 3 (1), 896-908.

Thoyibatun, Siti. 2009. Faktor-Faktor yang Berpengaruh terhadap Perilaku Tidak Etis dan Kecenderunagn Kecurangan Akuntansi serta Akibatnya terhadap Kinerja Organisasi. Ekuitas Jurnal Ekonomi dan Keuangan. 16 (2). hal. 245-260. Universitas Negeri Malang.

Tuanakotta, T.M. 2007. Akuntansi Forensik dan Audit Investigatif. Jakarta: Lembaga Penerbit Fakultas Ekonomi Universitas Indonesia.

Tunggal, Amin Widjaja. 2011. Pengantar Internal Auditing. Jakarta : Harvarindo.

Udayani, Anak Agung K. Finty. Sari, Maria M. Ratna. 2017. Pengaruh Pengendalian Internal dan Moralitas Individu pada Kecenderungan Kecurangan Akuntansi. EJurnal Akuntansi Universitas Udayana, 18(3), 1744-1799.

Ujiyantho, Muh. Arief. Pramuka, Bambang Agus. 2007. Mekanisme Corporate Governance, Manajemen Laba, dan Kinerja Keuangan. Simposium Nasional Akuntansi X : Makassar. 
Utama, Suyana. 2010. Aplikasi Analisis Kuantitatif. Edisi Keenam. Denpasar: Fakultas Ekonomi dan Bisnis Universitas Udayana.

Wilopo. 2006. Analisis Faktor-Faktor yang Berpengaruh Terhadap Kecenderungan Kecurangan Akuntansi Studi Pada Perusahaan Publik dan Perusahan Badan Usaha Milik Negara. SNA IX : Padang.

Zainal, Rizki. 2013. Pengaruh Efektivitas Pengendalian Intern, Asimetri Informasi_dan Kesesuaian Kompensasi Terhadap Kecenderungan Kecurangan Akuntansi (Fraud) (Studi Empiris Kantor Cabang Bank Pemerintah Dan Swasta Di Kota Padang). E-Journal Akuntansi Universitas Negeri Padang, 3 (1), 1-25. 